\title{
The effects of intraruminal infusions of acetic, propionic and butyric acids on the yield and composition of the milk of the cow
}

\author{
By J. A. F. ROOK AND C. C. BALCH \\ National Institute for Research in Dairying, Shinfield, Reading
}

(Received I December 1960-Revised I6 Fanuary I961)

In an earlier publication (Rook \& Line, I96I) it was suggested that the increases in the yield and solids-not-fat (s.N.F.) content of milk that occur in response to an improvement in the plane of energy nutrition of the cow are due to increases in the ruminal production of acetic and propionic acids. Evidence was given supporting the view that the acids differ in their effects on the synthesis of milk constituents by the mammary gland, acetic acid affecting synthesis of both lactose and proteins, propionic acid affecting specifically the synthesis of proteins.

The effect of the ruminal production of the volatile fatty acids on the fat content of milk is already well established (Balch, Balch, Bartlett, Bartrum, Johnson, Rowland \& Turner, 1955): unusually low fat contents occur when cows receive diets lacking in physical fibrousness, and these diets characteristically lead to a low ratio of acetic acid to propionic acid in the rumen. Balch \& Rowland (1959) suggested that the low fat content is due to a low ruminal production of acetic acid on these diets but, as discussed elsewhere (Rook, I959), the amounts of propionic and butyric acids produced in the rumen also may be important in determining the extent of fat synthesis in the mammary gland.

This paper describes three experiments to determine, with cows, the effects of continuous intraruminal infusions of acetic, propionic and butyric acids on the yield and composition of milk. Success was dependent on the development of a technique for the daily addition to the rumen of amounts of acids with a calorific value of not less than $4000 \mathrm{kcal}$, which is roughly equivalent to that of the smallest quantity of supplementary concentrates known from previous work (Rook \& Line, 196I) to produce significant changes in the yield and composition of milk. Previously volatile fatty acids have been added to the diets of dairy cattle as sodium salts of the acids, either mixed with the concentrate part of the diet or as a solution, sometimes in admixture with small quantities of acetic acid, given directly through a fistula into the rumen (Balch \& Rowland, I959; Tyznik \& Allen, I95I). In this way daily additions of up to I $\mathrm{kg}$ sodium acetate (the equivalent as acetic acid would provide I600 kcal) have been achieved, but larger quantities have produced harmful physiological effects (unpublished observation) probably resulting from the uptake of large amounts of sodium. A technique of infusing the acids in dilute aqueous solution directly into the rumen through a fistula suitable for continuous use over periods of several months was therefore developed in collaboration with Mr R. C. Campling of this Institute. 


\section{EXPERIMENTAI}

Animals and their management. Lactating Friesian cows with large permanent rumen fistulas were used in the three experiments. They were housed in an experimental byre and the management routine was normal.

Experimental design. The order of the treatments, details of which are given in Table I, followed a Latin square design in each experiment.

Table $\mathrm{x}$. Details of experimental design

\begin{tabular}{|c|c|c|c|c|c|c|c|}
\hline \multirow[b]{2}{*}{$\begin{array}{l}\text { Expt } \\
\text { no. }\end{array}$} & \multirow[b]{2}{*}{$\begin{array}{l}\text { No. of } \\
\text { cows }\end{array}$} & \multirow[b]{2}{*}{$\begin{array}{l}\text { Period of } \\
\text { experiment } \\
\text { (months of } \\
\text { lactation) }\end{array}$} & \multirow[b]{2}{*}{$\begin{array}{l}\text { Details } \\
\text { of Latin } \\
\text { square }\end{array}$} & \multirow[b]{2}{*}{$\begin{array}{l}\text { Duration } \\
\text { of each } \\
\text { treatment } \\
\text { (days) }\end{array}$} & \multicolumn{3}{|c|}{ Treatment } \\
\hline & & & & & & Infusion given daily & $\begin{array}{c}\text { Calories } \\
\text { supplied } \\
\text { (kcal/ } \\
\text { day) }\end{array}$ \\
\hline I & $3^{*}$ & 2nd-4th & $3 \times 3$ & 28 & (a) & $\begin{array}{l}\text { I0 gal water } \\
900 \mathrm{ml} \text { acetic acid + ro gal } \\
\text { water }\end{array}$ & $\overline{3300}$ \\
\hline & & & & & (c) & $\begin{array}{l}900 \mathrm{ml} \text { propionic acid }+ \\
\text { 10 gal water }\end{array}$ & $445^{\circ}$ \\
\hline 2 & $3^{*}$ & $5^{\text {th }}-8$ th & $3 \times 3$ & 24 & (a) & $\begin{array}{l}\text { I5 gal water } \\
\text { I500 ml acetic acid }+ \\
\text { I5 gal water }\end{array}$ & - \\
\hline & & & & & $(c)$ & $\begin{array}{l}1500 \mathrm{ml} \text { propionic acid }+ \\
15 \text { gal water }\end{array}$ & $745^{\circ}$ \\
\hline 3 & 4 & 2nd-6th & $\begin{array}{c}\text { Balanced } \\
4 \times 4\end{array}$ & 28 & (a) & 15 gal water & - \\
\hline & & & & & & $\begin{array}{l}\text { I430 } \mathrm{ml} \text { acetic acid }+ \\
\text { I5 gal water }\end{array}$ & 5250 \\
\hline & & & & & & $\begin{array}{l}\text { 1061 ml propionic acid }+ \\
\text { I5 gal water }\end{array}$ & 5250 \\
\hline & & & & & (d) & $\begin{array}{l}915 \mathrm{ml} \text { butyric acid }+ \\
15 \mathrm{gal} \text { water }\end{array}$ & 5250 \\
\hline
\end{tabular}

* The same cows were used in Expts $I$ and 2 but the order of treatments was reversed.

Foods. The daily basal diet consisted of hay $(16-18 \mathrm{lb} / \mathrm{cow})$ and dairy concentrate cubes (barley ${ }_{17}$, maize 20 , wheat bran 20 , decorticated groundnut meal ${ }_{5}$, copra cake Io, palm-kernel cake 5, molasses Io, dicalcium phosphate I, calcium carbonate $\mathrm{I}$, and salt $\mathrm{I} \%$, with $5 \times 10^{6}$ i.u. vitamin $\mathrm{A}$ and $\mathrm{I} \times 10^{6}$ i.u. vitamin $\mathrm{D}$ added per ton) given at a rate of $4 \mathrm{lb} / \mathrm{gal}$ in Expts I and 2 and at $3.3 \mathrm{lb} / \mathrm{gal}$ in Expt 3, according to the milk yield of a cow at the beginning of an experiment. The daily amount of cubes was decreased by $2 \mathrm{lb} / \mathrm{cow}$ at the end of each experimental period in Expt $\mathrm{I}$ and by $\mathrm{I} \cdot 5 \mathrm{lb}$ in Expt 3.

Treatments. The water and the diluted acids (see Table r) were given as continuous intraruminal infusions. From the first introduction of an acid, the daily amount was increased gradually from $500 \mathrm{ml}$ on the Ist day to the amounts shown in Table I

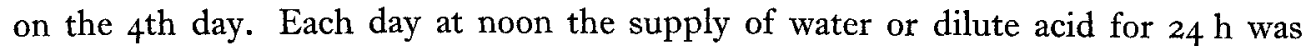
introduced into a reservoir above each cow and was allowed to flow into the rumen through a rubber tube. The tube passed through the inflated rubber bung that closed the fistula to a metal cage covered by a silk bag and anchored, a few inches above the 
floor of the rumen, by a weight. The rate of flow was adjusted, either by the insertion of a piece of glass capillary into the rubber tube or by a metal screw clip, to deliver the contents of the reservoir into the rumen in about $22 \mathrm{~h}$. During the infusions the animals drank little, if at all, and the total water intake was not markedly increased.

Sampling and methods of analysis. Milk yield was recorded, and samples of milk were taken at each milking during the three experiments and weighted composite samples representing successive 4 -day periods were prepared for each cow. All the composite samples were analysed for fat and total solids and, in addition, samples for the last two 4 -day periods of each treatment were analysed for lactose and total, noncasein and, in Expts 2 and 3 non-protein, nitrogen. The methods of analysis have been described previously (Rook \& Line, I961).

\section{RESULTS}

For the three experiments, the treatment mean values, with standard errors for the yield and composition of the milk, and the yields of milk constituents, over the last 8 days of each treatment period, are given in Table 2. The mean changes with time, for all the cows in all the experiments, in the yield and composition of the milk after the introduction of the supplements are presented graphically in Fig. I.

\section{Acetic-acid supplements}

The acetic-acid supplements consistently caused an increase in the yield of milk, an effect which was established progressively over a period of about 3 weeks, the mean increase ranging from $1.6 \mathrm{lb} / \mathrm{cow}$ daily in Expt 2 to $3.9 \mathrm{lb}$ in Expt 3 , and in Expts $\mathrm{I}$ and 3 the effects were significant $(P<0.05)$. The proportionate increases in yield in the three experiments were ${ }_{3}, 9$ and $12 \%$.

The supplements of acetic acid also increased the fat percentage in all experiments: the mean increase of 0.40 percentage units in Expt 3 was significant $(P<0.05)$, but the increases of 0.13 and 0.42 in Expts I and 2, respectively, did not reach significance $(P>0.05)$. An effect on fat percentage was observed in the first 4 -day sample after the introduction of the supplement, and was fully established with the second 4-day sample (see Fig. I). The effects on the percentages of S.N.F., lactose, protein (total $\mathrm{N} \times 6 \cdot 3^{8}$ ) and of the protein fractions in the milk were in general small and not consistent from experiment to experiment. In Expt 3, however, a significant $(P<0.05)$ decrease in the percentages of protein and soluble protein $\mathrm{N}$ (non-casein $\mathrm{N}$ less non-protein $\mathrm{N})$ and a significant $(P<0.05)$ increase in the percentage of lactose were observed. Determinations of the percentages of non-protein $\mathrm{N}$ were made only in Expts 2 and 3, but the concentrations in milk were decreased by the acetic-acid supplement in both experiments and by a highly significant $(P<0.0 \mathrm{I})$ amount in Expt 3. This effect reflects a more efficient use of food $\mathrm{N}$ during the period of aceticacid supplementation.

The daily yield of fat was increased by $18-27 \%$ by the acetic-acid supplements; these increases were about twice as great as those of $9-14 \%$ in the yields of milk, S.N.F., lactose and proteins. 


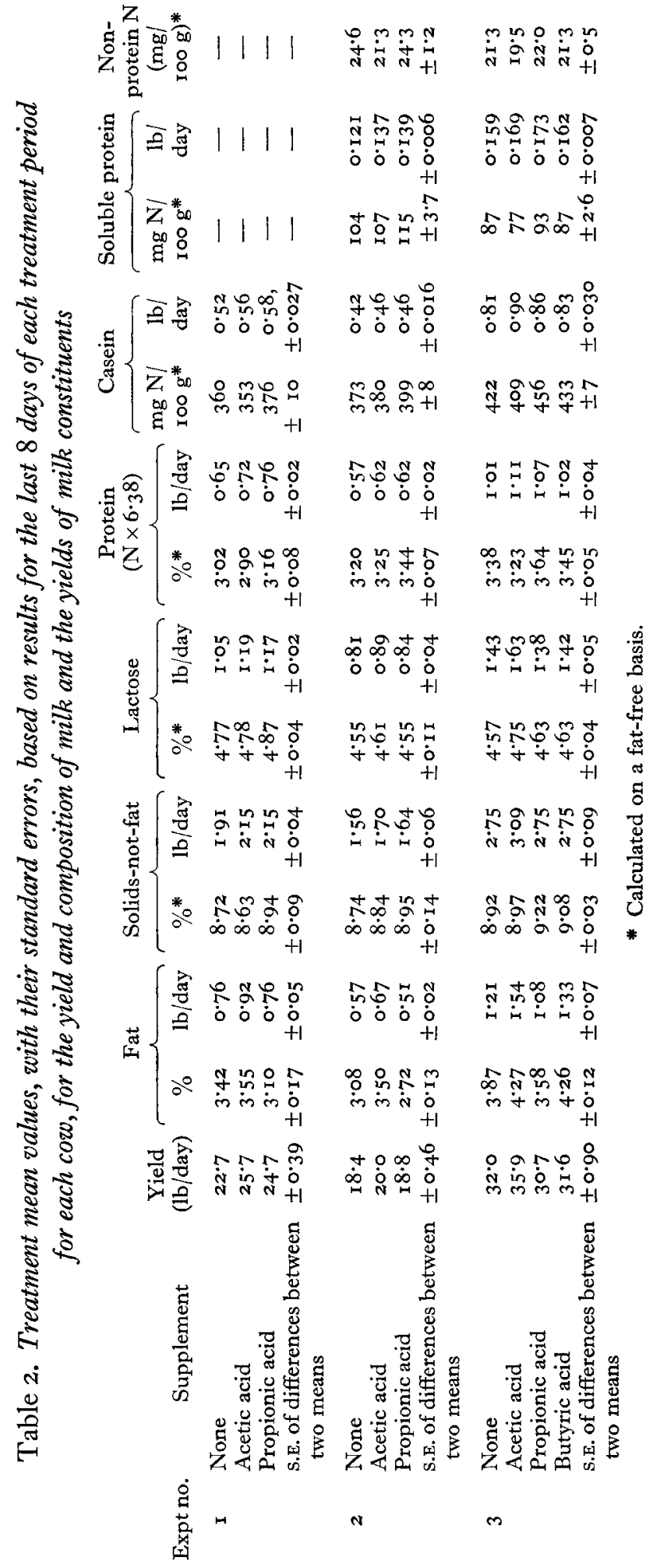




\section{Propionic-acid supplements}

With the supplements of propionic acid there were no consistent changes in the yields of milk; the small apparent changes varied in size from experiment to experiment and in no instance reached significance $(P>0.05)$. But consistent effects were observed on the contents of fat, S.N.F. and protein. The mean values for fat percentage over the last 8 days of propionic-acid supplementation were lower than the control values by $0.32,0.36$ and 0.29 percentage units in Expts I, 2 and 3 respectively, and the
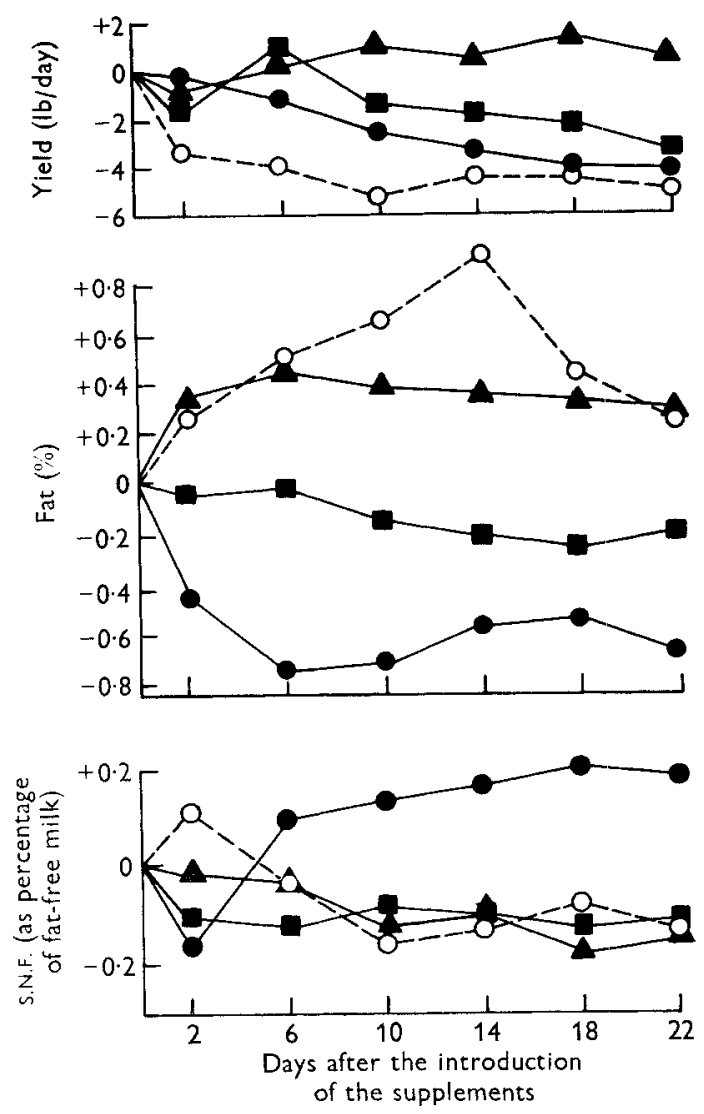

Fig. 1. Expts 1-3. Mean changes with time, for all the cows, in the yield and the fat and solids-not-fat contents of the milk after the introduction of intraruminal supplements of acetic, propionic or butyric acids. $\mathbf{D -}$, no supplement; $\boldsymbol{A}-\boldsymbol{\Delta}$, acetic-acid supplement; - propionic-acid supplement; $\mathrm{O}_{---O}$, butyric-acid supplement. The results for the butyric-acid supplement refer to Expt 3 only.

effect was significant $(P<0.05)$ in Expt 3 . As with the acetic-acid supplements, the effect on fat percentage was immediate, but the most pronounced effect, a mean decrease of 0.7 percentage units, occurred in the second 4-day sample after the introduction of propionic acid, and thereafter there was a partial recovery.

The mean increases in s.N.F. percentage in Expts $x, 2$ and 3 respectively, were 
$0.22,0.21$ and 0.30 percentage units, and in Expt 3 the effect was very highly significant $(P<0 \cdot 00 \mathrm{I})$. In contrast to the effect on fat percentage, the change was not immediate but, as with the effect of acetic acid on milk yield, it was established progressively over a period of about 3 weeks. The increases in S.N.F. percentage were due largely to increases in the percentages of casein and the soluble proteins, the proportionate increases in protein content in Expts I, 2 and 3 being 5, 8 and $8 \%$ respectively. There was no effect on the non-protein $\mathrm{N}$ content of the milk, and the changes in lactose content were small and not significant $(P>0.05)$.

The propionic-acid supplements increased the yield of milk proteins by $6-17 \%$, and decreased that of fat by up to $10 \%$, there being no consistent effect on the yield of lactose.

\section{Butyric-acid supplement}

The supplement of butyric acid given in Expt 3 had no effect on the yield of milk but increased significantly the fat percentage $(P<0.05)$ by a mean value of 0.39 over the last 8 days of the treatment period. This increase in fat content was equal to that obtained, in the same experiment, with an isocaloric supplement of acetic acid, but, owing to the unchanged milk yield, the increase in the yield of fat, of $10 \%$, was only one-third of that obtained with acetic acid. The effect of the butyric-acid supplement on fat percentage was at a peak, however, in the fourth 4-day sample after introduction of the supplement, showing a mean increase over the control value of $I \cdot I$, but thereafter the effect declined rapidly to less than half this value by the end of the treatment period. A significant $(P<0.05)$ increase in S.N.F. percentage of 0.16 was also obtained, but it was contributed to almost equally by increases in the lactose and protein contents which singly were not significantly increased $(P>0.05)$. There was no effect on the yield of s.N.F.

\section{DISCUSSION}

The characteristic effects of the intraruminal infusions of the individual steamvolatile fatty acids on the yield and fat and S.N.F. contents of milk are clearly shown in Fig. I. Acetic acid had a general effect; it increased the yield of milk and the yields of all milk constituents, and also specifically increased the fat percentage. In contrast, propionic and butyric acids affected only the composition of milk: propionic acid decreased the fat percentage and increased the protein, and hence the s.N.F., percentage, and butyric acid increased the fat percentage. Whereas the effects on fat content were apparent in the first 4-day sample of milk after the introduction of the acids, the effects on protein and S.N.F. contents, and on the yield of milk and the associated yields of milk constituents, were progressive and not fully established until about the $3^{\text {rd }}$ week of treatment.

In assessing the significance of these effects it is necessary to recognize that intraruminal additions of large amounts of organic acids may affect the fermentation of foodstuffs within the rumen. The distinct differences in the effects on the yield and composition of milk suggest, however, specific metabolic responses to the additions of the individual acids. 
The different effects of the individual volatile fatty acids on milk secretion could be, in part, due to the different sites of their metabolism. Of the three acids studied, acetate represents $90 \%$ or more of their total content in peripheral blood; propionate and butyrate, on absorption from the rumen, are metabolized almost wholly in the rumen wall or liver (see Annison, Hill \& Lewis, 1957). It is probable, therefore, that only acetate is directly utilized by mammary tissue in any quantity as a source of energy in the synthesis of fat, lactose and protein. Energy for synthetic reactions may be derived also from plasma glucose, but in the lactating cow (Rook \& Line, 196I) as in other ruminants (Reid, I950), homeostatic mechanisms normally maintain blood glucose concentration constant within narrow limits, and the supply to the mammary gland of substances utilized in the production of adenosinetriphosphate is likely to vary more markedly with the amount of acetate absorbed from the rumen than with the amounts of propionate or butyrate. It is reasonable, then, that the intraruminal infusion of acetate should affect the rate of synthesis of all milk constituents, and also the rate of milk secretion, because the mammary secretion is maintained isotonic with blood plasma and an increase in the rate of synthesis of lactose will increase the rate of output of water in milk (see also Rook \& Wood, I959). Since, with an increase in the uptake of acetate from the rumen, the proportionate increases in the yields of fat, lactose, protein and water would be roughly of the same order, an intraruminal addition of acetic acid would, according to this mechanism, be expected to give an increase in milk yield with but little change in milk composition. The observed increase in fat percentage in response to an acetic-acid supplement suggests, therefore, that acetate exerts also a specific effect on fat synthesis. Acetate is known to be a precursor of milk fat (Folley, I956; Glascock, 1958) and it is probable that the concentration of acetate in the arterial plasma, which gives some indication of the uptake of acetate from the rumen, determines the supply of acetate as precursor and affects the rate of synthesis of milk fat.

Though propionate and butyrate absorbed from the rumen cannot directly affect synthesis in the mammary gland, Armstrong \& Blaxter (1957) have shown that intraruminal additions of propionic or butyric acids, respectively, cause a decrease and an increase in the concentration of total ketone bodies in the peripheral blood. The observed effects of the intraruminal additions of propionic and butyric acids on fat content may therefore be due to an effect, on fat synthesis, of the concentration in arterial blood of $\beta$-hydroxybutyrate, since the latter is thought to be, like acetate, a precursor of milk fat (Folley, I956; Shaw \& Lakshmanan, I957; Glascock, I958). The tendency for the fat content to return to the pretreatment value after the first marked effect of intraruminal additions of either propionic or butyric acid may result from an adaptation in metabolism leading to a partial recovery of normal concentrations of $\beta$-hydroxybutyrate in the plasma (cf. Tepperman \& Tepperman, I958).

As suggested elsewhere (Rook, I959) the amount of propionate absorbed from the rumen may control also the overall degradation and synthesis of amino acids in the liver and thus affect the plasma concentration of amino acids and hence the rate of protein synthesis by the mammary gland since the major milk proteins are synthesized from the plasma amino acids (Barry, $195^{8}$ ). The precursor of lactose is the glucose of 
the plasma (Malpress, 1958), but because of the effectiveness of the mechanism controlling plasma glucose concentration it is unlikely that any end-product of food digestion would influence the rate of lactose synthesis without, as with acetate, at the same time influencing the rates of synthesis of other milk constituents.

The distinct patterns of change in milk synthesis with the intraruminal additions of the individual volatile fatty acids are of particular biochemical importance since they have been established in the intact animal and presumably have developed through metabolic pathways that quantitatively are of importance in relation to milk synthesis. The experimental results reported have side implications also in practical dairy husbandry since, together with the knowledge of the effect of the cow's diet on the ruminal production of the volatile fatty acids (Balch \& Rowland, 1957), they provide a sound background for advice to farmers when, owing to nutritional causes, milk is low in fat or S.N.F. It should now be possible by selection of feeds to obtain for milking cows rations which, in terms of the ruminal production of volatile fatty acids, are favourable to high milk yield, high fat content or high S.N.F. content. Such considerations and the possibilities of the use of the acids or their salts as supplements to rations for milking cows will be discussed more fully in subsequent publications.

\section{SUMMARY}

I. The effects on the yield and composition of the milk of the cow of intraruminal infusions of dilute aqueous solutions of individual volatile fatty acids, as supplements to a basal diet, have been determined in three experiments involving a total of seven cows: in the first two, infusions of acetic and propionic acid were compared, and in the third infusions of acetic acid, propionic and butyric acid; in all the experiments an infusion of water only was given as a control treatment.

2. A supplement of acetic acid caused an increase in milk yield and in the yields of fat, lactose and protein and a specific increase in fat percentage. Supplements of propionic or butyric acid had no effect on the yield of milk, but a propionic-acid supplement specifically decreased the yield and percentage of fat and increased the yields and percentages of protein and solids-not-fat, whereas a butyric-acid supplement specifically increased the yield and percentage of fat.

3. These distinct differences in the effects of the individual volatile fatty acids on the synthesis in the mammary gland of the major constituents of milk are discussed in relation to current knowledge of the metabolism of acetate, propionate and butyrate in the ruminant.

We thank Dr S. J. Rowland for his helpful interest in this work, Dr A. T. Cowie for establishing the rumen fistulas, $\mathrm{Mr} \mathrm{V}$. W. Johnson for his care of the experimental animals and Miss M. Wood and Miss M. J. Tong for their skilled technical assistance. 


\section{REFERENCES}

Annison, E. F., Hill, K. J. \& Lewis, D. (1957). Biochem. F. 66, 592.

Armstrong, D. A. \& Blaxter, K. L. (1957). Brit. F. Nutr. II, 4I3.

Balch, C. C., Balch, D. A., Bartlett, S., Bartrum, M. P., Johnson, V. W., Rowland, S. J. \& Turner, J. (1955). F. Dairy Res. 22, 270.

Balch, C. C. \& Rowland, S. J. (1959). F. Dairy Res. 26, 162.

Balch, D. A. \& Rowland, S. J. (1957). Brit. F. Nutr. xI, 288.

Barry, J. M. (1958). Proc. roy. Soc. B, 149, 380.

Folley, S. J. (1956). The Physiology and Biochemistry of Lactation. Edinburgh and London: Oliver and Boyd.

Glascock, R. F. (1958). Proc. roy. Soc. B, 149, 402.

Malpress, F. H. (1958). Proc. roy. Soc. B, 149, 362.

Reid, R. L. (1950). Aust. F. agric. Res. I, 182.

Rook, J. A. F. (1959). Proc. Nutr. Soc. 18, 117.

Rook, J. A. F. \& Line, C. (1961). Brit. F. Nutr, 15, 109.

Rook, J. A. F. \& Wood, M. (1959). Nature, Lond., 184, 647.

Shaw, J. C. \& Lakshmanan, S. (1957). A.A.A.S. Symp. 49, Atomic Energy and Agriculture, p. 305.

Tepperman, H. M. \& Tepperman, J. (1958). Diabetics, 7, 478.

Tyznik, W. \& Allen, N. N. (1951). F. Dairy Sci. 34, 493. 